\title{
Efficacy of first-line, WHO recommended generic HAART regimens in Indian children
}

\author{
Parakh A ${ }^{1}$, Dubey AP², Kumar $A^{3}$, Maheshwari $A^{4}$, Saxena $\mathbf{R}^{4}$ \\ ${ }^{1}$ Registrar, ${ }^{2}$ Professor and Head, ${ }^{3}$ Professor, ${ }^{4}$ Resident, Pediatric HIV Clinic, Department of Pediatrics, Maulana Azad \\ Medical College and Lok Nayak Hospital, New Delhi-110002, India.
}

\begin{abstract}
Background: The clinical efficacy of highly active antiretroviral therapy (HAART) in children has been well documented in the developed countries, although most of the regimens are Protease Inhibitor (PI) based which are too expensive. To circumvent this problem World Health Organization (WHO) has recommended Non- Nucleotide Reverse Transcriptase Inhibitor (NNRTI) based regimen for resource-limited countries.

Aim: To assess the long-term efficacy of first line World Health Organization (WHO)-recommended generic highly active antiretroviral therapy (HAART) regimens in treatment -naïve children.

Materials and methods: Observational retrospective analysis was done. Thirty patients on HAART for $\geq 6$ months were included (27 on Stavudine; three on Zidovudine with Lamivudine/ Nevirapine). No protease inhibitors were used. Results: median age was seven years (Interquartile [IQR]: 5.62-8.50) and median duration on HAART was 18 months (IQR: 6-24). No new staging events were observed after six months of initiation of HAART. The median CD4\% increased from $6.0 \%$ at baseline to $15.5 \%$ at six months, $21.7 \%$ at 12 months, $25.4 \%$ at 18 months, $24.6 \%$ at 24 months $25.3 \%$ at 30 months and $23.7 \%$ at 36 months. There was only one case of immunological failure. Stratified analysis based on baseline CD4 \% show that even patients with a baseline CD4 \% of $<5 \%$ achieved percentage of $>25 \%$ at $18-24$ months and maintained it subsequently. Significant increase in the weight and body mass index Z scores was observed but significant fall in the height $\mathrm{Z}$ scores were observed. This sub group of patients with poor linear height velocity would require detailed endocrine evaluation after testing for viral loads.

Conclusions: Non- Nucleotide Reverse Transcriptase Inhibitor based HAART regimens are feasible and effective in long term in resource-limited setting despite initiation of treatment in advanced stages. These can be continued in $\mathrm{NACO} / \mathrm{WHO}$ scale up programmes at present for children.
\end{abstract}

Key words: HAART in children, India, NNRTI based HAART, resource limited settings, WHO prequalified Antiretroviral therapy

$\mathrm{T}$ he clinical efficacy of highly active antiretroviral therapy (HAART) in children has been well documented in the developed countries, although most of the regimens are Protease Inhibitor (PI) based which are too expensive. To circumvent this problem World Health Organization (WHO) has recommended NonNucleotide Reverse Transcriptase Inhibitor (NNRTI) based regimen for resource-limited countries ${ }^{1}$. There are several reports on efficacy of these non-PI based regimens in adults ${ }^{2,3,4}$ and children ${ }^{5,6,7,8,9,10,11}$ but the data on Indian children is still limited ${ }^{12,13,14}$.

This observational retrospective analysis describes the clinical and immunologic effects of HAART in treatment -naïve, HIV infected Indian children with WHO prequalified first line regimens in a tertiary care hospital in north India.
Materials and methods

HIV-1 naïve infected children on HAART for a period of six or more months were included. All children were on first line WHO prequalified fixed-dose combinations (FDC) tablets of HAART provided by the National AIDS Control Organization (NACO) of India [Stavudine (D4T)/ Lamivudine (3TC)/Nevirapine (NVP) or Zidovudine (ZDV)/ Lamivudine (3TC)/Nevirapine (NVP)]. Patients received standard FDC in recommended doses (NVP (120-200 mg/m2 twice daily), ZDV (240 mg/m2 twice daily), d4T (1 mg/kg twice daily) and Lamivudine (4 $\mathrm{mg} / \mathrm{kg}$ twice daily)]. All patients were managed as per $\mathrm{WHO}^{1}$ and NACO guidelines ${ }^{15}$ and adverse events

\section{Correspondence}

Dr. Ankit Parakh

Jain's B-52, Ashoka Niketan

Delhi- 110092, India.

E-mail: ankitparakh102@rediffmail.com 
graded according to the US National Institutes of Health Division of AIDS ${ }^{16}$.

Patients were seen at enrolment and then followed prospectively for routine care monthly. At each visit, an interval history was obtained and physical examination conducted including anthropometric measurements. Adherence messages were reinforced at each patient contact. Serial clinical, immunological data and epidemiological data (age, sex) were recorded including mode of transmission, WHO clinical and immunological stage at diagnosis/ at beginning of HAART, HAART duration/regimen, serial anthropometry [height, weight, body mass index (BMI)] and WHO T stage. Changes from baseline in weight-for age $\mathrm{Z}$ score (WAZ), heightfor age $\mathrm{z}$ score (HAZ) and BMI-for age $\mathrm{z}$ score (BMIZ) at $6,12,24,30$ and 36 months were determined. Serial CD4 counts and percentages were measured at baseline and every six monthly by flow cytometry (Becton Dickinson, CA, USA). Similarly, changes from baseline in CD4 T cell counts, percentage and age adjusted ratios at the different time-points specified were determined. Viral load could not be done in any patient due to financial constraints and non-availability in the hospital.

To correct for the effect of the natural decline of CD4 cells with age, age-adjusted CD4 T-cell ratios were calculated by dividing the counts by the median for an age-matched healthy control group ${ }^{17}$. Growth was analyzed by serial $\mathrm{Z}$ scores of weight, height and BMI. $\mathrm{Z}$ scores were calculated using the program Nutstat, which is part of Epi Info (CDC, Atlanta). Wilcoxan's rank-sum test with Bonferroni modification was used to compute and evaluate the magnitude of change in CD 4 counts, percentages, ratios and anthropometric Z scores compared with baseline. Statistical significance was considered as $\mathrm{P}<0.05$ and all tests were two sided. Data were analysed with SPSS 13 (SPSS, Chicago, IL).

\section{Results}

Over a three years period (from 2005-2008), 130 children ( 85 boys, 45 girls) were diagnosed to have HIV-1 infection. HAART was started in 35 children, of these 30 children ( 23 boys, 7 girls) had a follow up of greater than six months. Further details are described for these 30 children only.

\section{Baseline characteristics}

Baseline characteristics of children are summarised in Table 1. Six $(20 \%)$ children were between one to three years, nine $(30 \%)$ between three to five years, and 15 $(50 \%)>5$ years of age. All patients were pre-pubertal. Twenty seven children had acquired HIV perinatally, with two having acquired through contaminated blood transfusions and one with mode of acquisition unknown.
Twenty seven of 30 children included were on $\mathrm{d} 4 \mathrm{~T} / 3 \mathrm{TC} /$ NVP and rest on ZDV/3TC/NVP. The median duration on HAART was 18 months (Interquartile [IQR]: 6-24). All patients took more than $95 \%$ of prescribed medications during the study period. None of the children had received any anti-retroviral drug for prevention of perinatal transmission. No additional nutritional supplements were provided.

\section{Clinical response and adverse drug events}

Three new staging were observed during the first six months of HAART (one case each of herpes zoster involving only the skin; oral candidiasis and cryptosporidium diarrhoea) but no new events were observed thereafter. During the 36 months of follow up one patient was lost to follow up due to unknown reasons. There have been no deaths in the study population. One patient developed immunological failure without clinical failure and shifted to second line drugs.

Four subjects had grade 2 and one subject had grade 3 signs or symptoms. Two subjects had grade 2 nausea and vomiting during the first week on the regimen, which resolved without intervention. Another two subjects had grade 2 rash, which subsided spontaneously. One subject had a grade 3 rash in the first week of therapy that led to change of study medication. Rest no other significant adverse drug reactions were observed.

Serial six monthly anthropometric $\mathrm{Z}$ scores are shown in Table 2 and Figure 1. The WAZ and BMIZ showed a statistically significant improvement on follow up. On the contrary there was no significant improvement in linear growth velocity with a consequent loss in serial HAZ.

\section{Immunological response}

There were eight $(27 \%)$ children with a baseline CD4 $\% \leq 5 \%, 19(63 \%)$ with CD $4 \%$ of $6-15 \%$ and three (10\%) with CD4\% of $>15 \%$. The median CD4 T-cell count, percentage and age-adjusted CD4 T-cell ratios demonstrated a statistically significant increase during the 36 months of treatment (Fig 2A, 2B and Table III). In addition, the rate of CD4 cell increase was greater during the first 18-24 months of therapy and plateued subsequently (Fig 2B). Stratified analysis based on baseline CD T cell percentages show that even patients with a baseline CD4 $\%$ of $<5 \%$ achieved percentage of $>25 \%$ at $18-24$ months and maintained it subsequently at that level as also observed in children with CD4\% of $5-15 \%$. Children with a baseline CD $4 \%$ of $>15 \%$ also showed significant rise in percentages and reached a median CD $4 \%$ of $38.42 \%$ at 18 months, $49.07 \%$ at 24 months and $45.49 \%$ at 30 months of HAART (Fig 2B). 


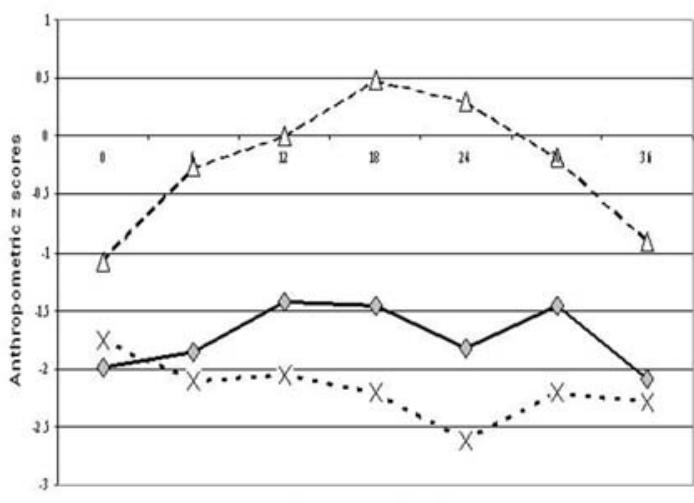

Months from start of HAART

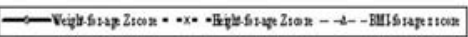

Fig 1: Weight, height and body mass index z-scores during 36 weeks of HAART

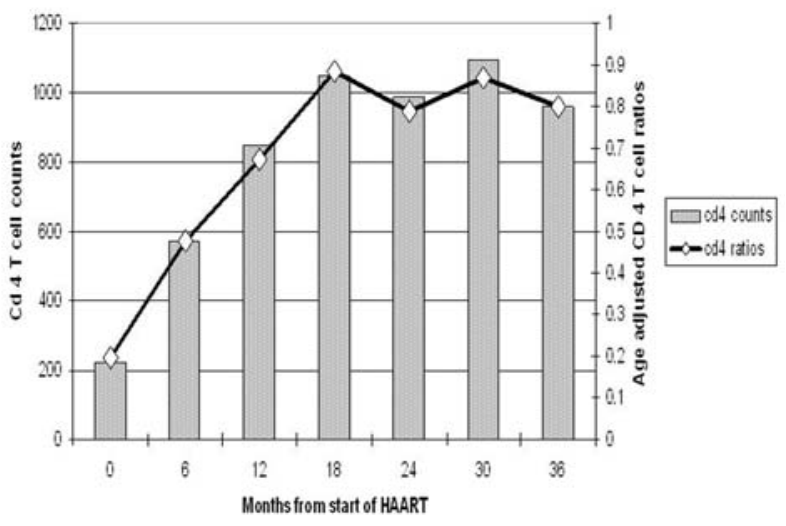

Fig 2A: CD 4 T cell counts and Age adjusted CD 4 T cell ratios during 36 weeks of HAART

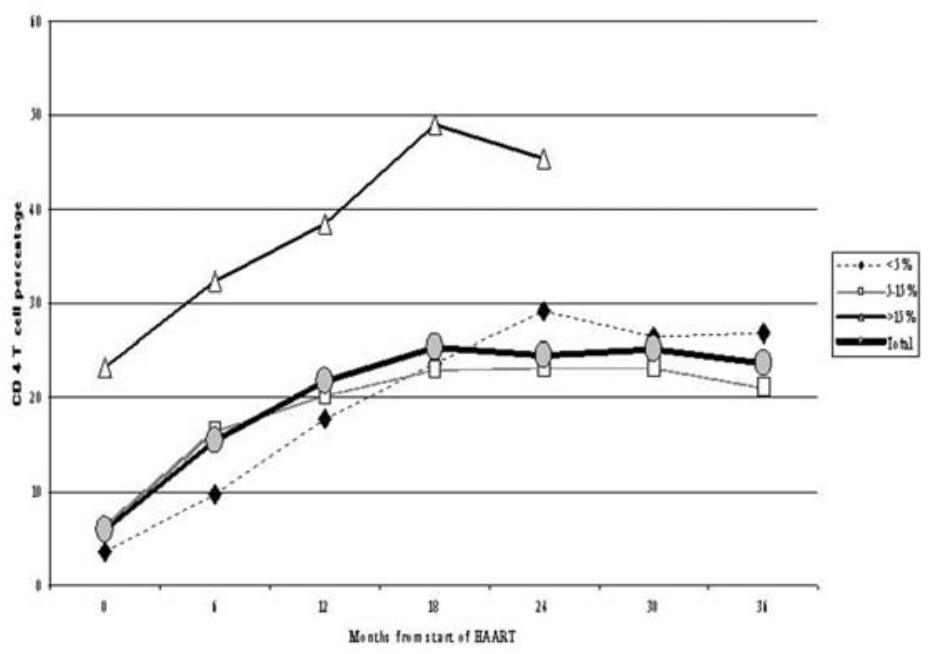

Fig 2B: Stratified CD 4 T cell percentages during 36 weeks of HAART

Table 1: Baseline characteristics of children

\begin{tabular}{|l|l|}
\hline Characteristic & Values \\
\hline No of patients & 30 \\
\hline Sex (female), $\mathrm{n}(\%)$ & $7(23 \%)$ \\
\hline Age, median (IQR), y & $7(5.62-8.50)$ \\
\hline Vertical transmission, $\mathrm{n}(\%)$ & $27(90 \%)$ \\
\hline WHO Clinical Stage, $\mathrm{n}(\%)$ & \\
\hline \multicolumn{1}{|c|}{ I } & $14(46.7 \%)$ \\
\hline \multicolumn{1}{|c|}{ II } & $1(3.3 \%)$ \\
\hline \multicolumn{1}{|c|}{ III } & $9(30 \%)$ \\
\hline \multicolumn{1}{|c|}{ IV } & $6(20 \%)$ \\
\hline CD4 counts T cells, median (IQR), No. per $\mu \mathrm{l}$ & $223(189.75-355.25)$ \\
\hline CD4 counts T cells, median (IQR), \% & $6.02(4.57-9.26)$ \\
\hline CD4 counts T cells, median (IQR), age adjusted ratios & $0.195(0.16-0.29)$ \\
\hline Weight- for-age z-score, median (IQR) & $-1.98(-4.51$ to -1.22$)$ \\
\hline Height for-age z-score, median (IQR) & $-1.75(-3.18$ to-- 0.92$)$ \\
\hline BMI for-age z-score, median (IQR) & $-1.08(-4.66$ to -0.32$)$ \\
\hline
\end{tabular}


Table 2: Weight, height and BMI z- scores at the different time-points

\begin{tabular}{|l|c|c|c|c|c|c|c|}
\hline & Baseline & $\mathbf{6 ~} \mathbf{~ m}$ & $\mathbf{1 2} \mathbf{~ m}$ & $\mathbf{1 8} \mathbf{~ m}$ & $\mathbf{2 4} \mathbf{~ m}$ & $\mathbf{3 0 ~} \mathbf{~ m}$ & $\mathbf{3 6} \mathbf{~ m}$ \\
\hline $\mathrm{N}$ & 30 & 30 & 22 & 16 & 16 & 6 & 2 \\
\hline $\begin{array}{l}\text { Weight- } \\
\text { for-age z } \\
\text { score }\end{array}$ & $\begin{array}{c}-1.980 \\
(-4.517 \text { to } \\
-1.220)\end{array}$ & $\begin{array}{c}-1.86(-3.08 \\
\text { to }-1.10)\end{array}$ & $\begin{array}{c}-1.43(-2.43 \\
\text { to }-0.79)\end{array}$ & $\begin{array}{c}-1.45(-2.22 \\
\text { to }-1.08)\end{array}$ & $\begin{array}{c}-1.82(-2.75 \\
\text { to }-0.96)\end{array}$ & $\begin{array}{c}-1.45(-2.63 \\
\text { to }-0.75)\end{array}$ & $\begin{array}{c}-2.08(-3.43 \\
\text { to }-0.74)\end{array}$ \\
\hline $\mathrm{P}$ value & 0.003 & 0.01 & 0.07 & 0.12 & 0.50 & 0.65 \\
\hline $\begin{array}{l}\text { Height- } \\
\text { for-age z } \\
\text { score }\end{array}$ & $\begin{array}{c}-1.75(-3.18 \\
\text { to }-0.92)\end{array}$ & $\begin{array}{c}-2.11(-3.01 \\
\text { to }-1.39)\end{array}$ & $\begin{array}{c}-2.05(-2.65 \\
\text { to }-1.27)\end{array}$ & $\begin{array}{c}-2.21(-2.78 \\
\text { to }-2.00)\end{array}$ & $\begin{array}{c}-2.61(-3.68 \\
\text { to }-2.19)\end{array}$ & $\begin{array}{c}-2.20(-2.79 \\
\text { to }-1.32)\end{array}$ & $\begin{array}{c}-2.29(-3.18 \\
\text { to }-1.40)\end{array}$ \\
\hline P value & 0.005 & 0.002 & 0.001 & 0.001 & 0.043 & \\
\hline $\begin{array}{l}\text { BMI- } \\
\text { for-age z } \\
\text { score }\end{array}$ & $\begin{array}{c}-1.08(-4.66 \\
\text { to } 0.32)\end{array}$ & $\begin{array}{c}-.25(-2.12 \\
\text { to } 0.49)\end{array}$ & $\begin{array}{c}.01(-2.09 \text { to } \\
1.10)\end{array}$ & $\begin{array}{c}.49(-.94 \text { to } \\
1.26)\end{array}$ & $\begin{array}{c}.31(-0.80 \text { to } \\
1.63)\end{array}$ & $\begin{array}{c}-.17(-0.76 \\
\text { to } 0.51)\end{array}$ & $\begin{array}{c}-.91(-1.83 \\
\text { to } 0.00)\end{array}$ \\
\hline P value & & 0.005 & 0.001 & 0.001 & 0.001 & 0.028 & 0.180 \\
\hline
\end{tabular}

Values represent median (IQR), all p values show comparison with baseline

Table 3: CD4 T cell counts, percentage and age adjusted ratios at the different time-points.

\begin{tabular}{|c|c|c|c|c|c|c|c|}
\hline & Baseline & $6 \mathrm{~m}$ & $12 \mathrm{~m}$ & $18 \mathrm{~m}$ & $24 \mathrm{~m}$ & $30 \mathrm{~m}$ & $36 \mathrm{~m}$ \\
\hline $\mathrm{N}$ & 30 & 30 & 22 & 16 & 16 & 6 & 2 \\
\hline $\begin{array}{l}\text { CD4 T } \\
\text { cells, No. } \\
\text { per } \mu \mathrm{l}\end{array}$ & $\begin{array}{c}223.0(189.7- \\
355.2)\end{array}$ & $\begin{array}{c}.477(.299- \\
.693)\end{array}$ & $\begin{array}{c}847.5(528.5- \\
1211.7)\end{array}$ & $\begin{array}{c}1046.5 \\
(755.0- \\
1343.7)\end{array}$ & $\begin{array}{c}986.0(819.5- \\
1504.0)\end{array}$ & $\begin{array}{c}815.0(740.7- \\
1371.0)\end{array}$ & $\begin{array}{c}961.0(865.0- \\
1057.0)\end{array}$ \\
\hline $\mathrm{P}$ value & & $<0.001$ & $<0.001$ & 0.001 & 0.001 & 0.046 & 0.655 \\
\hline $\begin{array}{l}\text { CD4 T } \\
\text { cells, } \%\end{array}$ & $\begin{array}{c}6.020(4.573- \\
9.267)\end{array}$ & $\begin{array}{l}15.544 \\
(9.403- \\
19.139)\end{array}$ & $\begin{array}{c}21.746 \\
(14.588- \\
30.617)\end{array}$ & $\begin{array}{c}25.440 \\
(17.753- \\
31.936)\end{array}$ & $\begin{array}{c}24.606 \\
(20.531- \\
39.888)\end{array}$ & $\begin{array}{c}25.233 \\
(20.921- \\
37.878)\end{array}$ & $\begin{array}{c}23.750 \\
(15.825- \\
26.091)\end{array}$ \\
\hline$P$ value & & $<0.001$ & $<0.001$ & 0.001 & 0.002 & 0.028 & 0.180 \\
\hline $\begin{array}{l}\mathrm{CD} 4 \mathrm{~T} \\
\text { cells, age } \\
\text { adjusted } \\
\text { ratios }\end{array}$ & $\begin{array}{c}0.196(0.167- \\
0.314)\end{array}$ & $\begin{array}{c}0.492(0.306- \\
0.716)\end{array}$ & $\begin{array}{c}0.671(0.457- \\
0.960)\end{array}$ & $\begin{array}{c}0.885(0.563- \\
1.012)\end{array}$ & $\begin{array}{c}0.788(0.654- \\
1.025)\end{array}$ & $\begin{array}{c}0.868(0.688- \\
1.212)\end{array}$ & $\begin{array}{c}0.800(0.700- \\
0.900)\end{array}$ \\
\hline$P$ value & & $<0.001$ & $<0.001$ & 0.001 & 0.003 & 0.028 & 0.180 \\
\hline
\end{tabular}

Values represent median (Interquartile), all p values show comparison with baseline

\section{Discussion}

As access to HAART improves with the aid of WHO "scale up" programmes increasing number of children are being started on WHO prequalified first line FDC [mainly d4T/3TC/NVP and occasionally ZDV/3TC/ NVP as the FDC preparations available for ZDV based therapy are only for $>20 \mathrm{~kg}$ at present in India]. With increasing numbers of years on HAART issues such as long-term efficacy and factors related to response, efficacy and failure of HAART are gaining importance. These are also important in assessing the need and quantity of second line ART at the national level.

Our study demonstrates the clinical and immunological efficacy of NNRTI-based regimen in Indian children in long term over 36 months. Only one case of immunological failure was observed. No significant new staging events were observed after six months of initiation of HAART. Statistically significant and sustained increase in CD4 T-cell counts, percentages and ratios were observed. Although, even patients with a baseline CD4 \% of $<5 \%$ achieved percentage of around $25 \%$ at $18-24$ months of HAART and maintained it subsequently, the sub group of patients with a baseline CD $4 \%$ of $>15 \%$ achieved much higher median CD $4 \%$ although the number of children in this subgroup was small. Data on tolerability of HAART in Indian children are limited, but we observed no unexpected adverse events that led to withdrawal or modification of treatment during follow up. 
Significant increase in the WAZ and BMIZ were observed. The reason why there was no significant increase in the linear height velocity is unclear in our patients. HAART restores or preserves growth in $\operatorname{most}^{17,18,19,20}$, but not all studies ${ }^{21}$. Possible reasons could include virological failure despite sustained rise in CD $4 \%$ or endocrine abnormalities such as hypothyroidism, growth hormone deficiency, low IGF-1/IGFBP3 and adrenal dysfunction $22,23,24,25,26$. This subgroup of patients would require detailed endocrine evaluation after testing for viral loads. It has been shown that height velocity is more closely related to HIV disease progression than weight velocity and should be incorporated as a composite end point for ART clinical trials in HIVinfected children ${ }^{27}$.

Limitations of our study include small cohort size with a variable period of follow-up, unicenteric, and disproportionately smaller number of patients in the ZDV/3TC/NVP arm. Disproportionately large number of older children, who are slow progressors, could also be a confounder explaining excellent response to HAART. Studies in a larger cohort including younger children with a longer follow-up period are needed to determine the duration of the clinical, virological, and immunological responses. Viral loads could not be determined due to poor availability and financial constraints.

\section{Conclusion}

Despite these limitations, our study demonstrates the long-term feasibility; effectiveness and tolerability of NNRTI- based HAART regimens in antiretroviral-naive, HIV-infected children in a resource-limited setting. The results showed an overall excellent clinical and immunological response to HAART despite initiation of treatment in advanced stages and comparable to other studies with no major adverse events. NNRTI based HAART regimens can be continued in NACO/ WHO scale up programmes at present.

\section{References}

1. World Health Organization. Scaling up Antiretroviral Therapy in Resource-limited Settings: Treatment Guidelines for a Public Health Approach. Geneva: World Health Organization; 2003.

2. Pujari SN, Patel AK, Naik E, Patel KK, Dravid A, Patel JK, et al. Effectiveness of generic fixeddose combinations of highly active antiretroviral therapy for treatment of HIV infection in India. J Acquir Immune Defic Syndr. 2004;37:1566-9.

3. Calmy A, Pinoges L, Szumilin E, Zachariah R, Ford N, Ferradini L, et al. Generic fixed-dose combination antiretroviral treatment in resource- poor settings: multicentric observational cohort. AIDS 2006;20:1163-9.

4. Siegfried NL, Van Deventer PJ, Mahomed FA, Rutherford GW. Stavudine, lamivudine and nevirapine combination therapy for treatment of HIV infection and AIDS in adults. Cochrane Database Syst Rev. 2006;2:CD004535.

5. Puthanakit T, Oberdorfer A, Akarathum N, Kanjanavanit S, Wannarit P, Sirisanthana T, et al. Efficacy of highly active antiretroviral therapy in HIV-infected children participating in Thailand's National Access to Antiretroviral Program. Clin Infect Dis. 2005;41:100-7.

6. Wamalwa DC, Farquhar C, Obimbo EM, Selig S, Mbori-Ngacha DA, Richardson BA, et al. Early response to highly active antiretroviral therapy in HIV-1-infected Kenyan children. J Acquir Immune Defic Syndr. 2007;45:311-7.

7. Zhou HY, Zheng YH, Zhang CY, Chen J, He Y, Ding PP, et al. Evaluation of human immunodeficiency virus type 1-infected Chinese patients treated with highly active antiretroviral therapy for two years. Viral Immunol. 2007;20:180-7.

8. Zhang F, Haberer JE, Zhao Y, Dou Z, Zhao $\mathrm{H}, \mathrm{He} \mathrm{Y}$, et al. Chinese pediatric highly active antiretroviral therapy observational cohort: a 1-year analysis of clinical, immunologic, and virologic outcomes. J Acquir Immune Defic Syndr. 2007;46:594-8.

9. Janssens B, Raleigh B, Soeung S, Akao K, Te V, Gupta J, et al. Effectiveness of highly active antiretroviral therapy in HIV-positive children: evaluation at 12 months in a routine program in Cambodia. Pediatrics 2007;120:e1134-40.

10. Bolton-Moore C, Mubiana-Mbewe M, Cantrell RA, Chintu N, Stringer EM, Chi BH, et al. Clinical outcomes and CD4 cell response in children receiving antiretroviral therapy at primary health care facilities in Zambia. JAMA 2007;298:1888-99.

11. Song R, Jelagat J, Dzombo D, Mwalimu M, Mandaliya K, Shikely K, et al. Efficacy of highly active antiretroviral therapy in HIV-1 infected children in Kenya. Pediatrics 2007;120:e85661.

12. Natu SA, Daga SR. Antiretroviral therapy in children: Indian experience. Indian Pediatr. 2007;44:339-43.

13. Lodha R, Upadhyay A, Kabra SK. Antiretroviral Therapy in HIV-1 Infected Children. Indian Pediatr. 2005;42:789-96.

14. Pensi T. Fixed dose combination of lamivudine, stavudine and nevirapine in the treatment of 
pediatric HIV infection: a preliminary report. Indian Pediatr. 2007:44:519-21.

15. National AIDS Control Organization. Guidelines for HIV care and Treatment in infants and children. India: NACO with support from Clinton Foundation, UNICEF and WHO; 2006.

16. HIV Prevention Trials Network [homepage on the Internet]. Divisions of AIDS, National Institute of Allergy and Infectious Diseases. Toxicity table for grading severity of pediatric adverse experiences, 1994. Available at: http://www.hptn.org/Web\%20Documents/ Regulatory_Resources.

17. Guillen S, Ramos JT, Resino R, Bellon JM, Munoz MA. Impact on Weight and Height With the Use of HAART in HIV-Infected Children. Pediatr Infect Dis J. 2007;26:334-8.

18. Nachman SA, Lindsey JC, Moye J. Growth of human immunodeficiency virus-infected children receiving highly active antiretroviral therapy. Pediatr Infect Dis J. 2005;24:352-7.

19. Verweel G, van Rossum AM, Hartwig NG, Wolfs TF, Scherpbier HJ, de Groot R. Treatment with highly active antiretroviral therapy in human immunodeficiency virus type 1-infected children is associated with a sustained effect on growth. Pediatrics. 2002;109: E25.

20. Dremaine D, Nielsen K, Deveikis A, Bryson YJ, Geffner ME. Effect of protease inhibitors combined with standard antiretroviral therapy on linear growth and weight gain in human immunodeficiency virus type 1-infected children. Pediatr Infect Dis J. 2001;20:315-6.
21. Nachman SA, Lindsey JC, Pelton S. Growth in human immunodeficiency virus-infected children receiving ritonavir-containing antiretroviral therapy. Arch Pediatr Adolesc Med. 2002;156:497-503.

22. Chiarelli F, Galli L, Verrotti A, diRocco L, Vierucci A, de Martino M. Thyroid function in childrenwithperinatalhumanimmunodeficiency virus type 1 infection. Thyroid. 2000;10:499 -505 .

23. Laue L, Pizzo PA, Butler K, Cutler GB Jr. Growth and neuroendocrine dysfunction in children with acquired immunodeficiency syndrome. J Pediatr. 1990;117:541-5.

24. Jospe N, Powell KR. Growth hormone deficiency in an 8-year old girl with human immunodeficiency virus infection. Pediatrics. 1990;86:309-12.

25. Frost RA, Nachman SA, Lang CH, Gelato MC. Proteolysis of insulin like growth factor-binding protein-3 in human immunodeficiency virus positive children with failure to thrive. J Clin Endocrinol Metab. 1996;81:2957-62.

26. Chantry CJ, Frederick MM, Meyer WA, Handelsman E, Rich K, Paul M E, et al. Endocrine Abnormalities and Impaired Growth in Human Immunodeficiency Virus-Infected Children. Pediatr Infect Dis J. 2007;26:53-60.

27. Benjamin Jr DK, Miller WC, Benjamine DK, Ryder RW, Weber DJ, et al. A comparison of height and weight velocity as a part of the composite endpoint in pediatric HIV. AIDS. 2003;17:2331-6. 